\title{
THE DISTRIBUTION OF IMMUNOREACTIVE $\alpha$-NEO-ENDORPHIN IN THE CENTRAL NERVOUS SYSTEM OF THE RAT
}

\author{
NADAV ZAMIR, ${ }^{1}$ MIKLOS PALKOVITS, AND MICHAEL J. BROWNSTEIN \\ Laboratory of Cell Biology, National Institute of Mental Health, Bethesda, Maryland 20205
}

Received July 29, 1983; Revised December 2, 1983; Accepted, December 2, 1983

\begin{abstract}
Using a specific radioimmunoassay, we have found that immunoreactive (ir) $\alpha$-neo-endorphin has a widespread and unique distribution in the rat brain and spinal cord. The highest concentration in brain is in the substantia nigra ( $1692.1 \mathrm{fmol} / \mathrm{mg}$ of protein). Very high concentrations of ir- $\alpha$-neoedorphin ( $>500 \mathrm{fmol} / \mathrm{mg}$ of protein) are also found in the lateral preoptic nucleus, dentate gyrus, parabrachial nuclei, nucleus accumbens, globus pallidus, median eminence, and anterior hypothalamic nucleus. Relatively high concentrations of ir- $\alpha$-neo-endorphin (250 to $500 \mathrm{fmol} / \mathrm{mg}$ of protein) are present in the bed nucleus of the stria terminalis, paraventicular nucleus, nucleus of the solitary tract, dorsomedial nucleus, central amygdaloid nucleus, periaqueductal gray matter, suprachiasmatic nucleus, periventricular nucleus, hippocampus, prepositus hypoglossal nucleus, arcuate nucleus, ventromedial nucleus, medial preoptic nucleus, zona incerta, dorsal premamillary nucleus, medial forebrain bundle (hypothalamic and preoptic), nucleus of the diagonal band, locus ceruleus, lateral septal nucleus, and nucleus ambiguus. Moderate levels (100 to $250 \mathrm{fmol} / \mathrm{mg}$ of protein) are found in the posterior hypothalamic nucleus, ventral premamillary nucleus, dorsal raphe nucleus, motor hypoglossal nucleus, caudate-putamen, periventricular thalamic nucleus, subcommissural organ, sensory trigeminal nucleus, perifornical nucleus, area postrema, supraoptic nucleus, cuneate nucleus, medial amygdaloid nucleus, and organum vasculosum laminae terminalis. Low concentrations of ir$\alpha$-neo-endorphin $(<100 \mathrm{fmol} / \mathrm{mg}$ of protein) are found in many cortical structures, claustrum, thalamic nuclei, habenular nuclei, lateral geniculate body, red nucleus, superior and inferior colliculi, paramedian reticular nucleus, pontine nuclei, superior olive, vestibular nuclei, motor facial nucleus, gigantocellular reticular nucleus, and subfornical organ. The lowest concentrations in brain $(<50$ $\mathrm{fmol} / \mathrm{mg}$ of protein) were measured in the olfactory bulb, and cerebellar cortex and nuclei. The spinal cord (cervical, thoracic, and lumbar segments) has low levels of ir- $\alpha$-neo-endorphin.
\end{abstract}

$\alpha$-Neo-endorphin is a 10 amino acid opioid peptide originally isolated from porcine hypothalami (Kangawa et al., 1979). It contains the amino acid sequence of leucine (Leu)-enkephalin at its amino terminus (Kangawa et al., 1981) and has extraordinary potency as an opiate agonist in the in vitro guinea pig myenteric plexuslongitudinal muscle bioassay (Kangawa et al., 1979, 1981; Oka et al., 1982). It appears to be highly selective $\kappa$ opiate agonist (Corbett et al., 1982; Oka et al., 1982). $\alpha$-Neoendorphin and the dynorphins are derived from a common precursor (prodynorphin) which contains three Leuenkephalin sequences (Kakidani et al., 1982). These correspond to neo-endorphin (Kangawa et al., 1981), dynorphin A (dyn A) (Goldstein et al., 1981), and dynorphin B (dyn B) (Kilpatrick et al., 1982), respectively.

Immunohistochemical studies have shown the existence of immunoreactive (ir) $\alpha$-neo-endorphin/dynorphin

\footnotetext{
${ }^{1}$ To whom correspondence should be addressed.
}

cell bodies, fibers, and terminals in the magnocellular hypothalamic nuclei, entorhinal cortex, central nucleus of the amygdala, hippocampal dentate gyrus, periaqueductal gray matter, parabrachial nuclei, brain stem reticular formation, nucleus of the spinal tract of trigeminal nerve, nucleus of the solitary tract, cuneate nucleus and the spinal cord (Weber er al., 1982a). In addition, ir- $\alpha$ neo-endorphin/dynorphin fibers or terminals were demonstrated in the cerebral cortex, olfactory bulh, nucleus accumbens, caudate-putamen, globus pallidus, hippocampus, preoptic area, median eminence, substantia nigra (reticular part), locus ceruleus, trigeminal sensory nucleus, motor facial nucleus, nucleus raphe magnus, certain vestibular and cochlear nuclei, reticular formation, and dorsal horn of the spinal cord, as well as the neural lobe of the pituitary (Weber et al., 1982a). Immunohistochemical methods allow precise localization of neuropeptides in brain structures but do not permit quantitation of the neuropeptide. Until now, the distri- 
bution of ir- $\alpha$-neo-endorphin in rat brain was based mainly on grossly dissected tissue samples. The highest concentrations of ir- $\alpha$-neo-endorphin were found in the posterior pituitary followed by the hypothalamus and striatum. High levels were also found in the hippocampus, midbrain, and spinal cord, whereas the cerebellum and cerebral cortex contained only low levels of ir- $\alpha$-neoendorphin (Minamino et al., 1981; Kitamura et al., 1982; Maysinger et al., 1982; Weber et al., 1982b). Accordingly, the present study of ir- $\alpha$-neo-endorphin distribution in rat brain and spinal cord by radioimmunoassay (RIA) after dissection of individual brain and spinal cord cell groups was undertaken.

\section{Materials and Methods}

Animals. Male Sprague-Dawley rats weighing 220 to 250 gm (Zivic Miller Laboratories, Inc., Allison Park, PA) were housed under alternate 12 -hr periods of dark and light (lights on 6:00 A.M. to 6:00 P.M.) and were given standard rat chow and tap water ad libitum.

Tissue preparation. All animals were killed by decapitation between 8:00 and 10:00 A.M. Their brains and spinal cords were quickly removed and frozen on dry ice. The spinal cords were dissected into cervical, thoracic, and lumbar segments. Individual brain nuclei were removed by the micropunch method (Palkovits, 1973) from $300-\mu \mathrm{m}$-thick coronal frozen sections cut in a cryostat at $-10^{\circ} \mathrm{C}$. Tissue from each microdissected brain area was pooled from two animals.

Tissue extraction. Tissue samples were placed in 1.5$\mathrm{ml}$ conical Eppendorf tubes containing $200 \mu \mathrm{l}$ of $0.1 \mathrm{~N}$ $\mathrm{HCl}$ and transferred to a boiling water bath for $10 \mathrm{~min}$. The tissue samples were then homogenized by sonication, and 20- $\mu \mathrm{l}$ aliquots of the homogenates were removed for protein determination (Lowry et al., 1951). The extracts were centrifuged at $2000 \times \mathrm{g}$ for $10 \mathrm{~min}$ at $4^{\circ} \mathrm{C}$; the supernatants were transferred to $12 \times 75 \mathrm{~mm}$ polypropylene tubes and evaporated to dryness in a Speed Vac Concentrator (Savant Instrument, Inc.). The residues were resuspended in buffer and ir- $\alpha$-neo-endorphin was measured by RIA. The efficiency of the extraction ( 80 to $90 \%$ ) was determined by measuring the recovery of $\left[{ }^{125} \mathrm{I}\right]-\alpha$-neo-endorphin internal standards.

RIA procedure. RIA was performed at $4^{\circ} \mathrm{C}$ in $100 \mathrm{mM}$ sodium phosphate buffer, $\mathrm{pH}$ 7.6. The assay buffer contained $0.1 \%$ Triton $\mathrm{X}-100,0.1 \%$ gelatin, $0.1 \%$ bovine serum albumin, and $0.01 \%$ merthiolate. One hundred microliters of standard ( $\alpha$-neo-endorphin) or unknown sample, $100 \mu \mathrm{l}$ of tracer (approximately $6000 \mathrm{cpm}$ of $\left[{ }^{125} \mathrm{I}\right]$ $-\alpha$-neo-endorphin), $100 \mu \mathrm{l}$ of antiserum (code Rl-3) diluted to one-fifth of its final dilution (final dilution $1: 60,000)$, and $200 \mu \mathrm{l}$ of assay buffer were added to polypropylene tubes. The tubes were then incubated at $4^{\circ} \mathrm{C}$ for 16 to $20 \mathrm{hr}$. Separation of bound and free peptides was effected by addition of $1 \mathrm{ml}$ of dextran-coated charcoal suspension. The tubes were vortexed, left for $10 \mathrm{~min}$ at $4^{\circ} \mathrm{C}$, and centrifuged at $4^{\circ} \mathrm{C}$ for $20 \mathrm{~min}$ at $2000 \times \mathrm{g}$. The supernatants were decanted into fresh $12 \times 75 \mathrm{~mm}$ glass tubes and counted in a gamma counter. At the dilution of the antiserum used, 30 to $45 \%$ of the counts added to each tube remained in the supernatant (i.e., were bound by the antibody) in the absence of standard or sample. The assay can reliably detect less than $4 \mathrm{pg} /$ tube.

Properties of the antiserum. The antiserum was a most generous gift of Dr. E. Weber (Stanford University, Palo Alto, CA). The specificity of the antiserum has been described (Weber et al., 1982b). It shows less than $0.1 \%$ cross-reactivity with $\beta$-neo-endorphin and does not cross-react with Leu-enkephalin, dyn A(1-6), dyn A(17), dyn A(1-8), dyn A(1-9), dyn A(1-13), dyn A, and $\alpha$ neo-endorphin (1-8) under the conditions of the RIA.

Peptides. $\alpha$-Neo-endorphin was purchased from Peninsula Laboratories (San Carlos, CA).

Iodination procedures. $\alpha$-Neo-endorphin was iodinated with $\mathrm{Na}^{125} \mathrm{I}$ using chloramine $\mathrm{T}$ (Hunter and Greenwood, 1982). The reaction was stopped with sodium metabisulfite, and the radiolabeled peptide was separated from free iodine by chromatography on Sep-Pak C18 cartridges (Waters Associates, Boston, MA) using increasing concentrations of methanol in $0.01 \mathrm{M} \mathrm{HCl} / 0.1 \mathrm{M}$ acetic acid.

\section{Results}

ir- $\alpha$-Neo-endorphin was present in all brain and spinal cord areas investigated. The peptide was unevenly distributed in the brain and spinal cord. In brain areas about a 40 -fold difference in ir- $\alpha$-neo-endorphin was detected between the richest (substantia nigra, 1692.1 $\mathrm{fmol} / \mathrm{mg}$ of protein) and the poorest (olfactory bulb, 41.6 $\mathrm{fmol} / \mathrm{mg}$ of protein) region. The cervical, thoracic, and lumbar segments of the spinal cord contain low levels of ir- $\alpha$-neo-endorphin.

Telencephalon. ir- $\alpha$-Neo-endorphin is unevenly distributed among telencephalic structures (Table I). Within the rhinencephalon, the olfactory bulk contains low levels of the peptide, whereas the olfactor $y$ tubercle and the nucleus of the diagonal band contain moderate and high levels of ir- $\alpha$-neo-endorphin, respectively. Cortical areas contain low concentrations of ir- $\alpha$-neo-endorphin (from $53.8 \mathrm{fmol} / \mathrm{mg}$ of protein in the frontal cortex to $114.1 \mathrm{fmol} / \mathrm{mg}$ of protein in the occipital cortex). A wide range of ir- $\alpha$-neo-endorphin concentrations exists in the limbic system. The hippocampus and dentate gyrus contain relatively large amounts of the peptide. Indeed, the latter has the highest concentration (676.3 $\mathrm{fmol} / \mathrm{mg}$ of protein) measured among the telencephalic structures. Amygdaloid nuclei hove moderate levels of the peptide. With the exception of the lateral septal nucleus, septal nuclei contain moderate levels of ir- $\alpha$ neo-endorphin. The basal ganglia (i.e., the rostral components of the extrapyramidal system) contain high levels of $\alpha$-neo-endorphin in the nucleus accumbens and globus pallidus, moderate levels in the caudate-putamen, and low levels of ir- $\alpha$-neo-endorphin in the claustrum.

Diencephalon (not including the hypothalamus). ir- $\alpha$ Neo-endorphin is unevenly distributed in the diencephalon (Table II). The zona incerta, which is richest in the peptide among the diencephalic nuclei $(360.7 \mathrm{fmol} /$ $\mathrm{mg}$ of protein), has a concentration 7.1 times greater than that found in the anterior ventral thalamic nucleus (50.5 fmol/mg of protein), which is poorest. Thalamic, epithalamic (habenula), and metathalamic (geniculate) structures all have low levels of ir- $\alpha$-neo-endorphin. The periventricular thalamic nucleus contains moderate lev- 
TABLE I

Distribulion of ir- $\alpha$-neo-endorphin in telencephalic nuclei of the rat

\begin{tabular}{|c|c|c|c|}
\hline & Regions & $\begin{array}{l}\text { ir- } \alpha \text {-Neo-Endorphin } \\
\text { Concentrations } \\
\text { (mean } \pm \mathrm{SEM})\end{array}$ & $\begin{array}{c}\begin{array}{c}\text { Molar Ratio } \\
(\alpha-\text { neo }+\beta-n e o)\end{array} \\
(\text { Dyn A + Dyn A(1-8)) }\end{array}$ \\
\hline & & $\begin{array}{c}\mathrm{fmol} / \mathrm{mg} \text { of } \\
\text { protein }\end{array}$ & \\
\hline 1 & Frontal cortex & $53.8 \pm 6.3(6)^{b}$ & 0.8 \\
\hline 2 & Cingulate cortex & $56.6 \pm 4.1(6)$ & 0.7 \\
\hline 3 & Piriform cortex & $92.8 \pm 9.4(6)$ & $-^{c}$ \\
\hline 4 & Parietal cortex & $56.8 \pm 4.8(6)$ & - \\
\hline 5 & Entorhinal cortex & $114.4 \pm 8.6(6)$ & - \\
\hline 6 & Occipital cortex & $99.8 \pm 14.6(6)$ & - \\
\hline 7 & Claustrum & $88.7 \pm 13.3(6)$ & - \\
\hline 8 & Hippocampus & $406.0 \pm 61.9(6)$ & 3.1 \\
\hline 9 & Dentate gyrus & $676.3 \pm 131.8(6)$ & - \\
\hline 10 & Olfactory bulb & $41.6 \pm 3.2(6)$ & - \\
\hline 11 & Olfactory tubercle & $175.5 \pm 9.9(5)$ & 1.1 \\
\hline 12 & Nucleus of the diagonal band & $334.3 \pm 32.7(6)$ & 1.9 \\
\hline 13 & Nucleus accumbens & $630.4 \pm 161.7(6)$ & 2.5 \\
\hline 14 & Bed nucleus of the stria terminalis & $454.1 \pm 53.3(6)$ & 2.4 \\
\hline 15 & Globus pallidus & $624.5 \pm 101.7(6)$ & 3.2 \\
\hline 16 & Caudate putamen & $235.6 \pm 19.0(6)$ & 1.9 \\
\hline 17 & Caudate nucleus & $172.4 \pm 18.6(6)$ & - \\
\hline 18 & Lateral septal nucleus & $292.7 \pm 39.6(6)$ & 2.1 \\
\hline 19 & Medial septal nucleus & $136.7 \pm 15.5(6)$ & 1.1 \\
\hline 20 & Dorsal septal nucleus & $139.9 \pm 20.9(5)$ & 1.4 \\
\hline 21 & Cortical amygdaloid nucleus & $101.7 \pm 7.7(6)$ & 1.3 \\
\hline 22 & Basal amygdaloid nucleus & $139.8 \pm 14.2(6)$ & 1.0 \\
\hline 23 & Medial amygdaloid nucleus & $184.8 \pm 25.9(6)$ & 1.8 \\
\hline 24 & Lateral amygdaloid nucleus & $152.4 \pm 18.6(6)$ & 1.4 \\
\hline 25 & Central amygdaloid nucleus & $424.5 \pm 65.3(6)$ & - \\
\hline
\end{tabular}

${ }^{a}$ Based on Zamir et al. $(1983,1984 a, c)$.

${ }^{b}$ Numbers in parentheses, numbers of samples.

${ }^{\circ}-$, no information.

TABLE II

ir- $\alpha$-Neo-endorphin concentrations in the diencephalic (except hypothalmic) nuclei of the rat

Regions

$\begin{array}{ll}26 & \text { Anterior ventral thalamic nucleus } \\ 27 & \text { Periventricular thalamic nucleus } \\ 28 & \text { Ventral thalamic nucleus } \\ 29 & \text { Medial thalamic nucleus } \\ 30 & \text { Nucleus reuniens } \\ 31 & \text { Rhomboid nucleus } \\ 32 & \text { Lateral thalamic nucleus } \\ 33 & \text { Parafascicular nucleus } \\ 34 & \text { Posterior thalamic nucleus } \\ 35 & \text { Lateral geniculate body } \\ 36 & \text { Medial geniculate body } \\ 37 & \text { Habenular nuclei (med. and lat.) } \\ 38 & \text { Zona incerta }\end{array}$

a Based on Zamir et al. (1983, 1984a, c).

${ }^{b}$ Numbers in parentheses, numbers of samples.

${ }^{\circ}-$, no information.

els of the peptide. The subthalamus (zona incerta) is rich in the peptide.

Hypothalamus. The hypothalamus is the richest brain region in ir- $\alpha$-neo-endorphin. The peptide is not evenly distributed among hypothalamic nuclei (Table III). Very high levels of ir- $\alpha$-neo-endorphin (above $500 \mathrm{fmol} / \mathrm{mg}$ of protein) were detected in the lateral preoptic area, median eminence, and anterior hypothalamic nuleus. High levels of the peptide (between 250 and $500 \mathrm{fmol} / \mathrm{mg}$ of protein) were found in the paraventricular, dorsomedial, suprachiasmatic, periventricular, arcuate, ventromedial, medial preoptic, and dorsal premamillary nuclei. High 
levels of the peptide were also measured in the medial forebrain bundle at both the hypothalamic and preoptic levels. Moderate levels of the peptide (between 100 and $250 \mathrm{fmol} / \mathrm{mg}$ of protein) were found in the posterior hypothalamic, ventral premamillary, perifornical, and supraoptic nuclei and in the mamillary body.

Mesencephalon. A wide range of ir- $\alpha$-neo-endorphin concentrations was found in the mesencephalon; there was approximately a 25 -fold difference between the highest peptide level in the mesencephalon $(1692.1 \mathrm{fmol} / \mathrm{mg}$ of protein in the substantia nigra) and the lowest (68.9 $\mathrm{fmol} / \mathrm{mg}$ of protein in the red nucleus) (Table IV). The substantia nigra has the highest ir- $\alpha$-neo-endorphin concentration in the central nervous system. The periaque-

TABLE III

$i r-\alpha-N e o-e n d o r p h i n$ content in nuclei of the hypothalamus

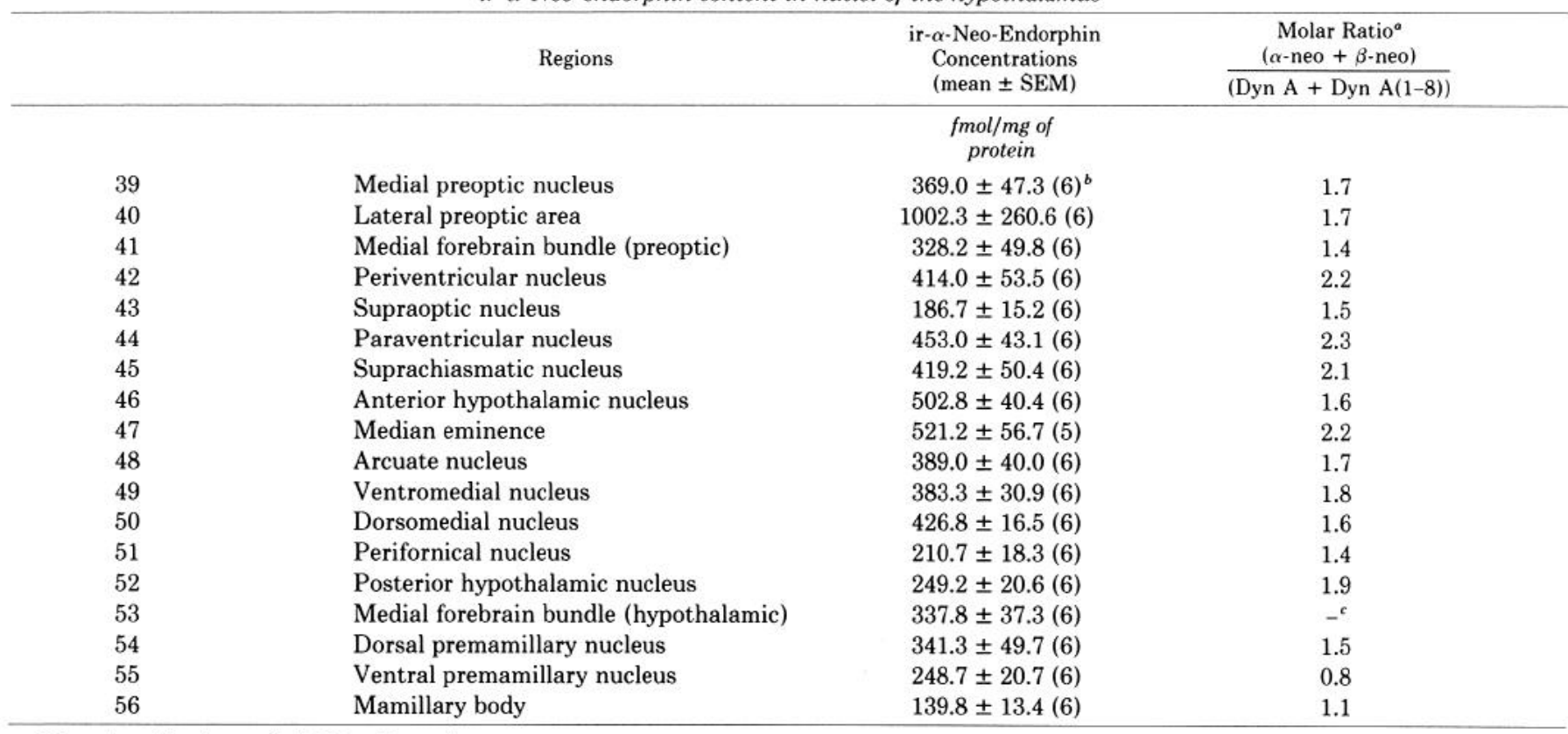

${ }^{a}$ Based on Zamir et al. (1983, 1984a, c).

${ }^{b}$ Numbers in parentheses, numbers of samples.

${ }^{c}-$, no information.

TABLE IV

ir- $\alpha$-neo-endorphin content in the mesencephalon and pons

ir- $\alpha$-Neo-Endorphin
Concentrations

Concentrations
(mean \pm SEM)

Molar Ratio

$(\alpha$-neo $+\beta$-neo $)$

$\mathrm{fmol} / \mathrm{mg}$ of

protein

Mesencephalon

$\begin{array}{ll}57 & \text { Substantia nigra } \\ 58 & \text { Ventral tegmental area } \\ 59 & \text { Interpeduncular nucleus } \\ 60 & \text { Red nucleus } \\ 61 & \text { Superior colliculus } \\ 62 & \text { Inferior colliculus } \\ 63 & \text { Periaqueductal gray matter (SGC) } \\ 64 & \text { Dorsal raphe nucleus } \\ 65 & \text { Cuneiform nucleus (ret. form.) } \\ \text { Pons } & \\ 66 & \text { Nucleus locus ceruleus } \\ 67 & \text { Parabrachial nuclei (dors. \& vent.) } \\ 68 & \text { Pontine tegmental nuclei } \\ 69 & \text { Pontine reticular nuclei (oral \& caud.) } \\ 70 & \text { Pontine nuclei } \\ 71 & \text { Superior olive } \\ 72 & \text { Motor trigeminal nucleus } \\ 73 & \text { Sensory trigeminal nucleus }\end{array}$

$\begin{array}{rl}1692.1 \pm 430.6(6)^{b} & 2.6 \\ 152.9 \pm 29.5(6) & 1.2 \\ 128.7 \pm 31.4(6) & 0.9 \\ 68.9 \pm 8.9(6) & 0.9 \\ 94.5 \pm 9.4(6) & 1.4 \\ 87.3 \pm 14.7(6) & 1.1 \\ 420.3 \pm 42.5(6) & 2.3 \\ 240.4 \pm 25.2(6) & 1.7 \\ 162.6 \pm 15.8(6) & 1.5 \\ & \\ 301.0 \pm 40.4(6) & 1.7 \\ 665.7 \pm 68.5(6) & 3.8 \\ 149.9 \pm 18.2(6) & 1.2 \\ 123.9 \pm 13.5(6) & 1.3 \\ 74.6 \pm 14.2(6) & 0.9 \\ 71.3 \pm 14.3(6) & 0.8 \\ 105.8 \pm 11.8(6) & 0.9 \\ 213.3 \pm 30.6(6) & 1.5\end{array}$

${ }^{a}$ Based on Zamir et al. $(1983,1984 a, c)$.

${ }^{b}$ Numbers in parentheses, numbers of samples. 
ductal gray matter also has a high level of the peptide. Low levels were measured in the superior and inferior collicles.

Pons. ir- $\alpha$-Neo-endorphin is distributed in a nonhomogenous pattern in the pons. There is approximately a 9.3-fold difference between the highest region (parabrachial nuclei, $665.7 \mathrm{fmol} / \mathrm{mg}$ of protein) and the lowest (superior olive, $71.3 \mathrm{fmol} / \mathrm{mg}$ of protein) (Table IV). The locus ceruleus contains a high level of the peptide. Low concentrations of the peptide were also found in the pontine nuclei.

Cerebellum. ir- $\alpha$-Neo-endorphin is present in the cerebellum but in very low concentrations (Table V). There is no substantial difference between the cortex (samples from both the vermis and hemispheres) and nuclei (all three nuclei were pooled).

Medulla oblongata. A wide range of ir- $\alpha$-neo-endorphin concentrations was found in the medulla oblongata. The richest area in ir- $\alpha$-neo-endorphin concentrations (nucleus of the solitary tract, medial part) contains 6.9 times as much of this peptide as the poorest (cochlear nuclei) (Table V). Among the cranial nerve nuclei the nucleus of the solitary tract (medial and commissural parts), prepositus hypoglossal nucleus, and nucleus ambiguus have high concentrations, whereas the vestibular nuclei (medial and lateral) and motor facial nucleus have low concentrations of the peptide. The nuclei of the reticular formation exhibit moderate to low levels of the peptide.

Circumventricular organs. Moderate concentrations of ir- $\alpha$-neo-endorphin were detected in all of the circumventricular organs except the subfornical organ, which has low levels of the peptide (Table VI).

Spinal cord. Low levels of ir- $\alpha$-neo-endorphin are present in all spinal cord segments assayed (Table VII). The cervical spinal cord has the highest concentration of ir$\alpha$-neo-endorphin and the lumbar segment has the lowest.

Pituitary gland. The neurointermediate lobe of the pituitary gland contains substantial amounts of ir- $\alpha$-neoendorphin (Table VIII).

\section{Discussion}

The quantative distribution of the opioid peptide, $\alpha$ neo-endorphin, has been determined in discrete areas of rat brain and in the spinal cord by RIA. Our results show that ir- $\alpha$-neo-endorphin is present throughout the brain and spinal cord but is heterogenously distributed.

The antiserum used in the present study has been described (Weber et al., 1982b). It appears to be quite specific for $\alpha$-neo-endorphin. It reacts very poorly (less than $0.01 \%$ ) with $\beta$-neo-endorphin and does not react with dyn-A and its fragments or Leu-enkephalin. Because $\alpha$-neo-endorphin shares a common precursor with

TABLE V

ir- $\alpha$-Neo-endorphin concentrations in medulla oblongata and cerebellum

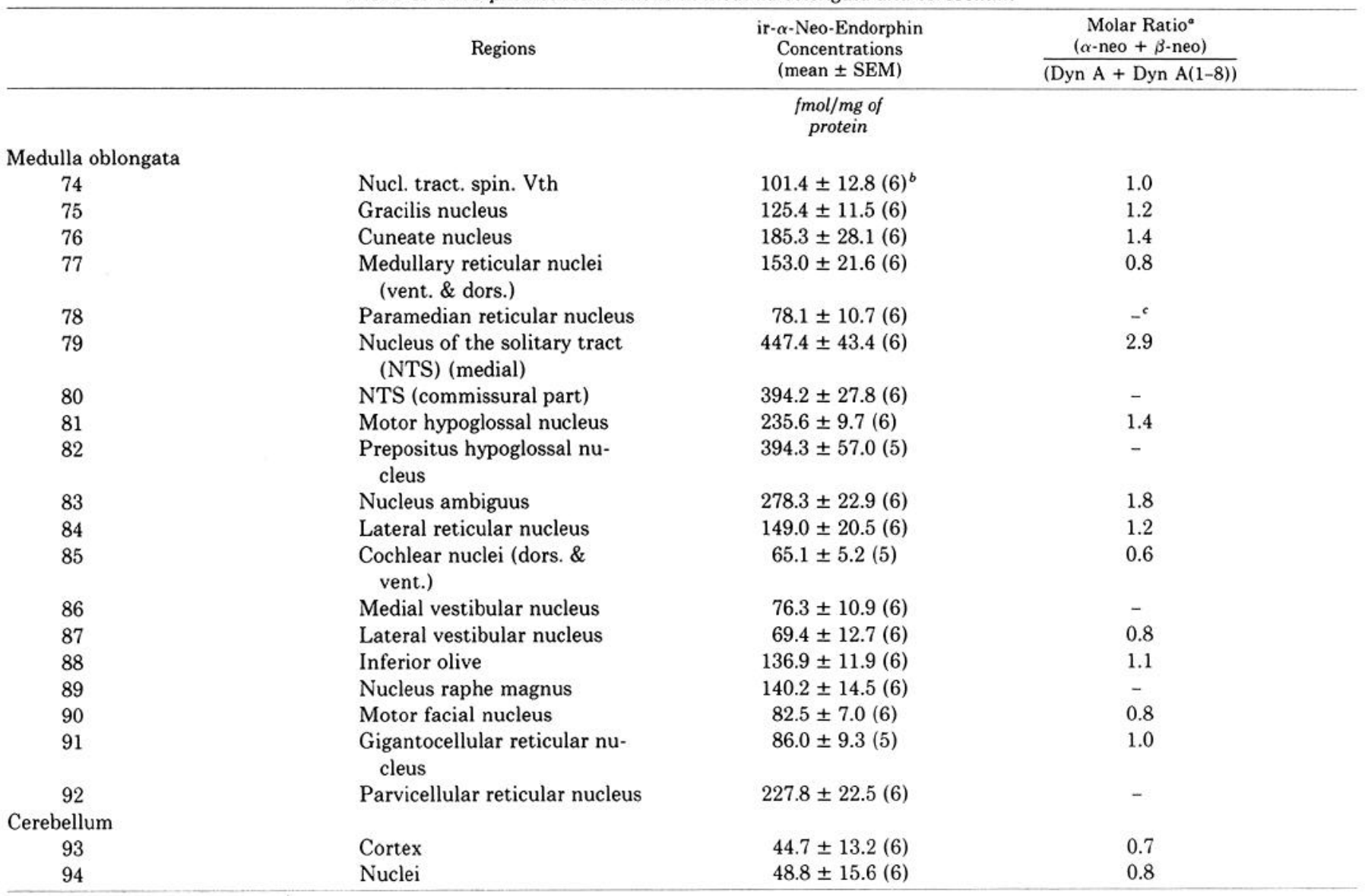

${ }^{a}$ Based on Zamir et al. (1983, 1984a, c).

${ }^{b}$ Numbers in parentheses, numbers of samples.

${ }^{c}-$, no information. 
TABLE VI

Concentrations of ir- $\alpha$-neo-endorphin in the circumventricular organs

\begin{tabular}{|c|c|c|c|}
\hline & Regions & $\begin{array}{l}\text { ir- } \alpha \text {-Neo-Endorphin } \\
\text { Concentrations } \\
\text { (mean } \pm \text { SEM) }\end{array}$ & $\begin{array}{c}\text { Molar Ratio }{ }^{\circ} \\
(\alpha-\text { neo }+\beta \text {-neo }) \\
\text { (Dyn A + Dyn A (1-8)) }\end{array}$ \\
\hline & & $\begin{array}{l}\mathrm{fmol} / \mathrm{mg} \text { of } \\
\text { protein }\end{array}$ & \\
\hline 95 & $\begin{array}{l}\text { Organum vasculosum laminae } \\
\text { terminalis }\end{array}$ & $164.0 \pm 17.0(6)^{b}$ & 1.1 \\
\hline 96 & Subfornical organ & $72.0 \pm 14.2(6)$ & 0.7 \\
\hline
\end{tabular}

${ }^{a}$ Based on Zamir et al. $(1983,1984 a, c)$.

${ }^{b}$ Numbers in parentheses, numbers of samples.

TABLE VII

Distribution of ir- $\alpha$-neo-endorphin in the spinal cord

\begin{tabular}{ccc}
\hline Areas & $\begin{array}{c}\text { ir- } \alpha \text {-Neo-Endorphin } \\
\text { Concentrations } \\
\text { (mean } \pm \text { SEM) }\end{array}$ & $\begin{array}{c}\text { No. of } \\
\text { Samples }\end{array}$ \\
\hline fmol/mg of \\
protein \\
$132.4 \pm 26.4$ & \\
Cervical & $82.6 \pm 9.2$ & 6 \\
Thoracic & $59.2 \pm 7.8$ & 6 \\
Lumbar & & 6 \\
\hline
\end{tabular}

TABLE VIII

Content of ir- $\alpha$-neo-endorphin in neurointermediate lobe of the pituitary gland

\begin{tabular}{ccc}
\hline Region & $\begin{array}{c}\text { ir- } \alpha \text {-Neo-Endorphin } \\
\text { Concentrations } \\
\text { (mean } \pm \text { SEM) }\end{array}$ & $\begin{array}{c}\text { Molar Ratio } \\
(\alpha-\text { neo }+\beta \text {-neo })\end{array}$ \\
\hline $\begin{array}{c}\text { fmol/mg of } \\
\text { protein }\end{array}$ & \\
Neurointer- & Dyn A + Dyn A (1-8)) \\
mediate lobe & $10,209.6 \pm 860.3(18)^{b}$ & 3.2 \\
\hline
\end{tabular}

${ }^{a}$ Based on Zamir et al. (1983, 1984a, c).

${ }^{b}$ Number in parentheses, number of samples.

dyn $\mathrm{A}$ and dyn $\mathrm{B}$, we supposed that they might have parallel distributions. This proved not to be the case; the ratio of a $\alpha$-neo-endorphin to dyn A varies from region to region.

About $75 \%$ of the brain areas examined have greater concentrations of $\alpha$-neo-endorphin and $\beta$-neo-endorphin than of dyn $A$ and dyn $A(1-8)$. This is in spite of the fact that the antiserum (Lucia) used for measuring dyn A in our earlier study (Zamir et al., 1983) is fully crossreactive with dyn $\mathrm{A}$, dyn(1-24), dyn(1-32), and even bigger segments of the prodynorphin (Ghazarossian et al., 1980; Fischli et al., 1982).

There are several areas, in fact, where the ratio of $\alpha$ neo-endorphin to dyn $\mathrm{A}$ is very large: substantia nigra (17.2 times); dentate gyrus and globus pallidus ( $>8$ times): nucleus accumbens, hippocampus, lateral preoptic area, and parabrachial nuclei ( 6 -fold difference), and nucleus of the solitary tract (medial part), periaqueductal gray matter, central and medial amygdaloid nuclei, caudate-putamen, bed nucleus of stria terminalis, and several cortical areas such as piriform, entorhinal, and occipital (4- to 5-fold difference).

Some nuclei do contain more dyn A than $\alpha$-neo-en- dorphin. Typically, these are nuclei in which the level of $\alpha$-neo-endorphin is rather low, not nuclei with strikingly high dyn A concentrations. Among the structures that fall into this class are anterior ventral thalamic nucleus, medial and lateral thalamic nucleus, and habenular nuclei in the diencephalon; red nucleus in the mesencephalon, superior olive in the pons, cochlear nuclei of the medulla oblongata, and the cerebellar cortex and nuclei. There are also areas in which the molar ratio between the two peptides is about 1, e.g., cingulate cortex, and claustrum of the telencephalon, the rhomboid nucleus, ventral premamillary nucleus, and mamillary body of the diencephalon; pontine nuclei in the pons, and several nuclei of the medulla oblongata such as motor facial nucleus, gigantocellular reticular nucleus, and area postrema.

The fact that the majority of brain areas studied have considerably more $\alpha$-neo-endorphin than dyn $\mathrm{A}$ is consistent with the idea that dyn-A serves chiefly as a precursor for another peptide. Dyn $\mathrm{A}(1-8)$ has been detected in the brain, but the sums of the concentrations of dyn $\mathrm{A}$ and dyn $\mathrm{A}(1-8)$ in most brain regions are less than the sums of the concentrations of $\alpha$-neo-endorphin and $\beta$-neo-endorphin (Tables I to VI, and VIII). This suggests that dyn A gives rise to a product or products other than dyn $\mathrm{A}(1-8)$. One possibility is that dyn A serves as a precursor for Leu-enkephalin (just as proenkephalin does). Recently, in fact, we have shown that the Leu-enkephalin in the substantia nigra is almost exclusively in neo-endorphin/dynorphin-containing neuronal processes contributed by cells in the rostral striatum (Zamir et al., 1984b).

Our data are in good agreement with reports describing the quantitative distribution of ir- $\alpha$-neo-endorphin in gross anatomical regions (Minamino et al., 1981; Maysinger et al., 1982; Weber et al., 1982b). They also agree reasonably well with those obtained by immunohistochemistry (Weber et al., 1982a). It seems that nuclei with high concentrations of ir- $\alpha$-neo-endorphin contain large numbers of ir- $\alpha$-neo-endorphin fibers and terminals. Thus, the most dense $\alpha$-neo-endorphin-positive fiber networks were found in the posterior lobe (Ito et al., 1981 ), which has very high levels of ir- $\alpha$-neo-endorphin $(10,209.6 \mathrm{fmol} / \mathrm{mg}$ of protein). The substantia nigra (reticular part) contains a large number of ir fibers and terminals and the highest concentration of ir- $\alpha$-neoendorphin in brain (1692.1 fmol/mg of protein). Other 
areas rich in positive ir- $\alpha$-neo-endorphin fibers and terminals such as nucleus accumbens, globus pallidus, lateral preoptic area, median eminence, and locus ceruleus contain substantial amounts of the peptide. The supraoptic nucleus, entorhinal cortex, caudate nucleus, some brain stem reticular formation nuclei, nucleus of the spinal tract of trigeminal nerve, cuneate nucleus, and spinal cord (marginal zone) all have $\alpha$-neo-endorphinpositive cell bodies (Weber et al., 1982a; Watson et al., 1982) and have moderate levels of the peptide. This is consistent with the observation that precursors once synthesized are rapidly transported away from cell bodies (Brownstein et al., 1980). Thus, precursors and their products do not accumulate in areas with abundant perikarya but in regions that are densely innervated.

There are exceptions to the rule that cell body-rich areas are not rich in ir- $\alpha$-neo-endorphin; the paraventricular nucleus, arcuate nucleus, the hippocampal dentate gyrus, the mesencephalic periaqueductal gray matter, parabrachial nuclei, and nucleus of the solitary tract have high concentrations of ir- $\alpha$-neo-endorphin and contain ir- $\alpha$-neo-endorphin cell bodies (Weber et al., 1982a). In these regions the peptide may be present in axons or terminals of the intrinsic neurons. There are also apparent exceptions to the dogma that regions that seem to be densely innervated by $\alpha$-neo-endorphin-positive fibers are rich in peptide. Thus, the nucleus of the spinal tract of trigeminal nerve, which contains numerous thin $\alpha$ neo-endorphin fibers and terminals, contains relatively low amounts of the peptides.

Based on the anatomical studies that have been reported to date, it seems safe to conclude that enkephalinand prodynorphin-derived peptides exist in separate populations of neurons form $\beta$-endorphin (Watson et al., 1982). $\beta$-Endorphin cell bodies are clustered in the arcuate nucleus and tuberal region (Bloom et al., 1978). The fiber system originating from these neurons is distributed rostrally in the region of the anterior commis. sure, extending into the lateral septum and nucleus accumbens. The ir fibers are abundant in midline periventricular regions of the hypothalamic and midline structures of the thalamus. Scattered fibers are also present in a number of brain stem structures including the periaqueductal gray matter, nucleus of the solitary tract, and locus ceruleus. $\alpha$-Neo-endorphin/dynorphin and enkephalin cell bodies, on the other hand, have been visualized throughout the telencephalon, diencephalon, brain stem, and spinal cord (Simantov et al., 1977; Sar et al., 1978). A comparison of the distribution of the two peptide families reveals many overlaps and discrepancies. For example, the highest concentration of ir- $\alpha$-neo-endorphin but not enkephalins was found in the substantia nigra. The highest concentrations of methionine (Met)enkephalin were found in the globus pallidus and bed nucleus of stria terminalis (Kobayashi et al., 1978), areas that are also rich in $\operatorname{ir}-\alpha$-neo-endorphin. Substantial amounts of ir- $\alpha$-neo-endorphin and relatively low amounts of enkephalins (Kobayashi et al., 1978; Dupont et al., 1980) exist in the hippocampus. Because the Leuenkephalin sequence appears in both prodynorphin (3 copies) and proenkephalin (1 copy), it seems likely that Leu-enkephalin is derived from the two separate precur- sors. This may explain why the ratio of Leu-enkephalin to Met-enkephalin varies in different brain regions.

The widespread distribution of ir- $\alpha$-neo-endorphin in cell bodies and fibers in brain and spinal cord as revealed by immunohistochemistry and confirmed by RIA indicates that this opioid peptide may have a role in diverse physiological functions. The presence of a large number of ir- $\alpha$-neo-endorphin-positive fibers and terminals and substantial amounts of the peptide in the sustantia nigra, interpeduncular nucleus, ventral pallidum, caudate-putamen, globus pallidus, and nucleus accumbens is particularly suggestive of a role for $\alpha$-neo-endorphin in motor function. The substantial amounts of ir- $\alpha$-neo-endorphin in the substantia nigra may indicate that this area can serve as a major site for interaction between ir- $\alpha$-neoendorphin and the dopaminergic system. The findings that cell bodies containing dynorphin in the caudate project to the substantia nigra indicate the existence of a further striatonigral pathway (Vincent et al., 1982). $\alpha$ Neo-endorphin and other prodynorphin-derived peptides may also have a major role in the neuroendocrine system. This is supported by the presence of ir- $\alpha$-neo-endorphin and dynorphin perikarya in the supraoptic and paraventicular nuclei, which have been observed also to contain vasopressin (Watson et al., 1982). Some of these cells give rise to ir- $\alpha$-neo-endorphin/dynorphin fibers in the internal layer of the median eminence and the posterior lobe of the pituitary (Palkovits et al., 1983). In addition, the lateral preoptic area, median eminence, medial preoptic area, suprachiasmatic nucleus, anterior hypothalamic nucleus, arcuate nucleus, and central amygdaloid nucleus may represent sites at which $\alpha$-neoendorphin could affect the neuroendocrine system.

The results of the present study and immunohistochemical work suggest that sensory functions might be influenced by $\alpha$-neo-endorphin at several levels of the central nervous system. These include the nucleus of the solitary tract, where dynorphin may regulate input from the baro- and chemoreceptive afferents, the periaqueductal gray, the nucleus raphe magnus, and the dorsal horn of the spinal cord (Palkovits and Zaborszky, 1978; Duggan, 1983).

\section{References}

Bloom, F., E. Battenberg, J. Rossier, N. Ling, and R. Guillemin (1978) Neurons containing $\beta$-endorphin in rat brain exist separately from those containing enkephalin: Immunocytochemical studies. Proc. Natl. Acad. Sci. U. S. A. 75: 15911595.

Brownstein, M. J., T. Russel, and H. Gainer (1980) Synthesis, transport, and release of posterior pituitary hormones. Scicnce 207: 323380 .

Corbett, A. D., S. J. Paterson, A. T. McKnight, J. Magnan, and H. W. Kosterlitz (1982) Dynorphin $1-8$ and dynorphin D. $_{1-9}$ are ligands for the kappa-subtype of opiate receptor. Nature 299: $79-81$.

Duggan, A. W. (1983) Electrophysiology of opioid peptides and sensory systems. Br. Med. Bull. 39: 65-70.

Dupont, A., N. Barden, L. Cusan, Y. Merand, F. Labrie, and M. Vaudry (1980) $\beta$-Endorphin and Met-enkephalins: Their distribution, modulation by estrogens and haloperidol, and role in neuroendocrine control. Fed. Proc. 39: 2544-2550.

Fischli, W., A. Goldstein, M. W. Hunkapiller, and L. E. Hood 
(1982) Isolation and amino acid sequence analysis of a 4000 dalton dynorphin from porcine pituitary. Proc. Natl. Acad. Sci. U. S. A. 79: 5435-5437.

Ghazarossian, V. F., C. Chavkin, and A. Goldstein (1980) A specific radioimmunoassay for the novel opioid peptide dynorphin. Life Sci. 27: 75-86.

Goldstein, A., W. Fischli, L. I. Lowney, M. Hunkapiller, and L. Hood (1981) Porcine pituitary dynorphin: Complete amino acid sequence of the biologically active heptadecapeptide. Proc. Natl. Acad. Sci. U. S. A. 78: 7219-7223.

Hunter, W. M., and F. C. Greenwood (1962) Preparation of iodine-131 labeled human growth hormone of high specific activity. Nature 194: 495-496.

Ito, S., I. Iwanaga, R. Yui, K. Yamaguchi, H. Hama, K. Kamoi, and A. Shibata (1981) Presence of $\alpha$-neo-endorphin-like immunoreactivity in the posterior lobe of the pituitary gland. Life Sci. 29: 1457-1461.

Kakidani, H., Y. Furutani, H. Takahashi, M. Noda, Y. Morimoto, T. Hirose, M. Asai, S. Inayama, S. Nakanishi, and S. Numa (1982) Cloning and sequence analysis of cDNA for porcine $\beta$-neo-endorphin/dynorphin precursor. Nature 298: $245-249$.

Kangawa, K., H. Matsuo, and M. Igarashi (1979) $\alpha$-neo-endorphin: A "big" Leu-enkephalin with potent opiate activity from porcine hypothalami. Biochem. Biophys. Res. Commun. 86: $153-160$.

Kangawa, K., N. Minamino, N. Chino, S. Sakakibara, and H. Matsuo (1981) The complete amino acid sequence of $\alpha$-neoendorphin. Biochem. Biophys. Res. Commun. 99: 871-888.

Kilpatrick, D. L., A. Wahlstrom, H. W. Lahm, R. Blacher, and S. Udenfriend (1982) Rimorphin, a unique, naturally occurring (leu) enkephalin-containing peptide found in association with dynorphin and $\alpha$-neo-endorphin. Proc. Natl. Acad. Sci. U. S. A. 79: 6480-6483.

Kitamura, K., N. Minamino, Y. Hayashi, K. Kangawa, and H. Matsuo (1982) Regional distribution of $\beta$-neo-endorphin in rat brain and pituitary. Biochem. Biophys. Res. Commun. 109: 966-974.

Kobayashi, R. M., M. Palkovits, R. J. Miller, K. -J. Chang, and P. Cuatrecasas (1978) Brain enkephalin distribution is unaltered by hypophysectomy. Life Sci. 22: 527-530.

Lowry, O. H., N. J. Rosebrough, A. L. Farr, and R. J. Randall (1951) Protein measurement with the Folin phenol reagent. J. Biol. Chem. 193: 265-275.

Maysinger, D., V. Höllt, B. R. Seizinger, L. Mehraein, A. Pasi, and A. Herz (1928) Parallel distribution of immunoreactive $\alpha$-neo-endorphin and dynorphin in rat and human tissue. Neuropeptides 2: 211-225.

Minamino, N., K. Kitamura, Y. Hayashi, K. Kangawa, and H. Matsuo (1981) Regional distribution of $\alpha$-neo-endorphin in rat brain and pituitary. Biochem. Biophys. Res. Commun. 102: $226-234$.

Oka, T., K. Negishi, M. Kajiwara, Y. Watanabe, Y. Ishizuka, and T. Matsumiya (1982) The choice of opiate receptor subtype by neo-endorphins. Eur. J. Pharmacol. 79: 301-305.

Palkovits, M. (1973) Isolated removal of hypothalamic or other brain nuclei of the rat. Brain Res. 59: 449-450.

Palkovits, M., and L. Zaborszky (1978) Neuroanatomy of central cardiovascular control. Nucleus tractus solitarii: Afferent and efferent neuronal connections in relation to the baroreceptor arc. Prog. Brain Res. 47: 9-34.

Palkovits, M., M. J. Brownstein, and N. Zamir (1983) Immunoreactive dynorphin and $\alpha$-neo-endorphin in rat hypothalamo-neurohypophysial system. Brain Res. 278: 258-261.

Sar, M., W. E. Stumpf, R. J. Miller, K. -J. Chang, and P. Cuatrecasas (1978) Immunohistochemical localization of enkephalin in rat brain and spinal cord. J. Comp. Neurol. 182: 17-38.

Simantov, R., M. J. Kuhar, G. R. Uhl, and S. H. Snyder (1977) Opioid peptide enkephalin: Immunohistochemical mapping in rat central nervous system. Proc. Natl. Acad. Sci. U. S. A. 74: $2167-2171$.

Vincent, S., T. Hökfelt, I. Christensson, and L. Terenius (1982) Immunohistochemical evidence for a dynorphin immunoreactive striato-nigral pathway. Eur. J. Pharmacol. 85: 251252.

Watson, S. J., H. Akil, W. Fischli, A. Goldstein, E. Zimmerman, G. Nilaver, and T. B. VanWimersma Greidanus (1982) Dynorphin and vasopressin: Common localization in magnocellular neurons. Science 216: 85-87.

Watson, S. J., H. Khachaturian, H. $\Lambda$ kil, D. H. Coy, and A. Goldstein (1983) Comparison of the distribution of dynorphin systems and enkephalin systems in brain. Science 218: 1134-1136.

Weber, E., K. A. Roth, and J. D. Barchas (1982a) Immunohistochemical distribution of $\alpha$-neo-endorphin/dynorphin neuronal systems in rat brain: Evidence for colocalization. Proc. Natl. Acad. Sci. U. S. A. 79: 3062-3066.

Weber, E., C. J. Evans, J.-K. Chang, and J. D. Barchas (1982b) Brain distributions of $\alpha$-neo-endorphin and $\beta$-neo-endorphin: Evidence for regional processing differences. Biochem. Biophys. Res. Commun. 108: 81-88.

Zamir, N., M. Palkovits, and M. J. Brownstein (1983) Distribution of immunoreactive dynorphin in the central nervous system of the rat. Brain Res. 280: 81-93.

Zamir, N., M. Palkovits, and M. J. Brownstein (1984a) Distribution of immunoreactive dynorphin $\mathrm{A}(1-8)$ in discrete nuclei of the rat brain; comparison with dynorphin A. Brain Res., in press.

Zamir, N., M. Palkovits, E. Weber, E. Mezey, and M. J. Brownstein (1984b) A dynorphinergic pathway of Ieu-enkephalin production in rat substantia nigra. Nature 307 : 643-645.

Zamir, N., M. Palkovits, and M. J. Brownstein (1984c) Distribution of immunoreactive $\beta$-neo-endorphin in discrete areas of the rat brain and pituitary gland: Comparison with $\alpha$-neoendorphin. J. Neurosci. 4: 1248-1252. 